\title{
Diagnosis-Related Groups (DRG) and Hospital Business Performance Management
}

\author{
Piotr Szynkiewicz ${ }^{1}$, Petre Iltchev ${ }^{2}$, Anna Piechota ${ }^{3}$, \\ Aleksandra Sierocka ${ }^{4}$, Michał Marczak ${ }^{2}$ \\ 1 CEO, Prometriq, Sopot, Poland \\ 2 Health Care Policy Department, Medical University of Lodz, Poland \\ 3 Department of Insurance, University of Lodz, Poland \\ ${ }^{4}$ K. Jonscher Hospital in Lodz, Poland
}

\begin{abstract}
The goal of this article is to present the possibility of using DiagnosisRelated Groups (DRG) in the hospital management process and to analyse the need for business performance management on the part of hospital management staff. The following research methods were used: literature analysis, case studies, and poll analysis. It is not possible to increase the effectiveness of operation of healthcare entities without increasing the importance of IT systems and using DRG more effectively in the management process. Training users in IT and the use of DRGs is important to achieving hospital effectiveness. The increased importance of analyses and planning in a hospital should be reflected in the organisational structure of service providers. Hospital controllers should have a similar role to those present in most companies in other industries.
\end{abstract}

\section{Introduction}

The goal of this article is to present the role of Diagnosis-Related Groups (DRG) in hospital business performance management. In order to demonstrate the role of DRGs in this process, an analysis of literature was performed, and a vision of process development in Poland was presented, based on a poll determining the demand for business performance management by the hospital management staff. After studying the issues related to the development of DRGs and using them in the management of medical facilities, we have attempted to adapt the experiences of other Organisation for Economic Co-operation and Development (OECD) countries to Polish conditions. By presenting the best case studies and standards in this field, we hope that we will support managers in the process of management improvement by proposing new ideas, innovative solutions and best practices. 


\section{Piotr Szynkiewicz et al.}

The importance of hospital financing results from their share of the public payers' budget (the National Health Fund). Table 1 presents the share of hospital financing in the Polish public payers' budget - the National Health Fund (NFZ).

Table 1. The share of hospital financing in the Polish public payers' budget the National Health Fund (NFZ)

\begin{tabular}{|l|c|c|c|c|c|c|c|}
\hline \multirow{2}{*}{ Indicator } & \multicolumn{7}{|c|}{ Year } \\
\cline { 2 - 8 } & 2008 & 2009 & 2010 & 2011 & 2012 & 2013 & 2014 \\
\hline $\begin{array}{l}\text { Value of hospital treatment financing } \\
\text { (billions of PLN) }\end{array}$ & 23.79 & 26.05 & 27.06 & 27.38 & 29.56 & 30.15 & 27.23 \\
\hline Total NFZ costs (billions of PLN) & 51.66 & 58.48 & 60.23 & 61.26 & 65.26 & 66.99 & 67.06 \\
\hline $\begin{array}{l}\text { Share of hospital treatment in the NFZ } \\
\text { budget (\%) }\end{array}$ & 46.06 & 44.05 & 44.93 & 44.70 & 45.29 & 45.02 & 40.60 \\
\hline
\end{tabular}

Source: Own work based on NFZ financial data.

Analysis of the value of finances received by hospitals in the period of 2008 to 2014 indicates that since 2008, hospitals have received more funding than the entire NFZ budget in 2003 (22.208 billion PLN according to the financial plan for the year 2003 from 18 July 2003). The share of hospitals in the NFZ budget in the 2008 to 2014 period was at the level of 40.6 percent in 2014 (plan) up to 46.06 percent in 2008. For the 2008 to 2013 period, we observed a continuous increase of hospital contracts with the NFZ. In 2014, a sudden decrease of hospital financing by the NFZ occurred - allocated resources decreased by 10 percent compared to 2013. In case contracts with the NFZ are not increased, the optimisation of operation - increasing effectiveness by eliminating unnecessary costs and maximising the use of available resources - remains available to hospitals as one of the possible ways to increase effectiveness. Effective hospital management is important for two reasons. The first reason is that in accordance with article 59.1 of the Act on Medical Activity of 15 April 2011, "an independent public health care institution will cover its negative financial result on its own". In accordance with the Act on Medical Activity of 15 April 2011, public hospitals are required to balance profits and losses (after adding amortization). Otherwise the founding body is required to cover the loss, to transform or to liquidate the hospital (Ustawa z dnia 15 kwietnia 2011 o działalności leczniczej, 2011). The second reason is that increasing the effectiveness of hospital operation may reduce the increase of resources assigned to the health care system. It should be noted that the increase of hospital effectiveness is not under- 
stood by the authors as simple restriction of operational costs (most Polish hospitals have already undergone such actions). We understand increasing effectiveness to mean implementation of a product strategy - that is, controlling the profile of offered services, which leads to concentrating on selected areas of activity, and thus to achieving a permanent competitive advantage (cooperation abilities) by better adapting competences and resources to the production profile, and thereby reducing the costs of acquiring skills and resources in other areas.

In 2008, a Diagnosis-Related Groups (DRG) system was introduced in Poland as a basis for settlements between hospitals and the public payer (NFZ). The increase of the role of insurance companies in the financing of additional health care services anticipated in the future will probably also be based on the DRG system. Due to this fact, in the subsequent part of the article we shall present the role of DRGs in hospital business performance management.

\section{DRGs and Hospital Business Performance Management}

The implementation of DRGs required hospitals to invest in employee training and in adapting IT systems. These investments will be much more effective when, in addition to generating obligatory reports, they will also be used to improve the effectiveness of hospital operation. The obtained information should be used as widely as possible. This also applies to DRG reports for the NFZ. To this purpose, answers should be sought to questions like: To what ends may DRG be used in the hospital management process? Some of these answers depend on the implemented IT system.

In 2008, directly after the implementation of the DRG system in Poland, it was not used in hospital strategic management, due to lack of knowledge and experience, as well as the lack of implemented controlling systems. Due to the fact that data concerning DRGs are the foundation for the process of delivering analytical management information, answers to the following questions should be sought:

- What is the goal of using DRGs in hospital management, what benefits may result thereof?

- How may DRGs improve the analysis of hospital operation and result in increased effectiveness?

- What indicators are important for hospital management?

- What indicators are available on the NFZ website, which provides DRG statistical data? 


\section{Piotr Szynkiewicz et al.}

Regardless of available studies on hospital finance management (Gierusz et al, 2009; Hass-Symotiuk, 2011; Jaworzyńska, 2010; Rój et al, 2006; Stępniewski, 2008), hospital business performance management remains unpopular and rarely used in practice in Poland.

Electronic medical records (electronic medical patient documentation) are the source of information that may form the basis for calculating costs at the lowest level. Grouping of depersonalised data from the medical patient record, combined with financial information, enables obtaining cost calculations in such dimensions as: DRG unit, medical procedures and processes, organisational unit - cost/profit centre (place where the costs are created), medical personnel/medical team, hospital ward etc. Comparing the costs collected in the medical patient file with the ones in the diagnosisrelated group enables establishing whether in the given case the hospital bears a loss or generates profit. Human and physical resources, which are available to the hospital for contracts, as well as the costs borne, are the basis for break- even point analysis at the DRG level. This analysis enables hospital managers to establish which DRG procedures / services should be kept and which should be abandoned, if the hospital is unable to decrease costs and increase contract amounts.

In hospital management, we use data and analysis that depends on the goals we set, the time horizon of decisions which have been made, and decision needs. The analysis of costs and profitability of services has a special place. The hospital business performance management problem is related to the fact that there are no detailed data and that the hospital organisational structure and level of responsibility are not adapted to the requirements of this management concept. The hospital organisational structure should undergo changes intended to link rights and duties with the responsibility for financial results and with the motivation system. Planning and budgeting should be a significant element of the hospital management process. Within this context, it is worth asking the following questions:

- To what degree are hospitals and their management interested in Business Performance Management type systems?

- Which business performance management tools may utilise DRG data to the widest extent?

In practice, answers to these questions depend on the availability of solutions with the aforementioned functionalities, implementation costs, and the automation of cost data collection. Not the least important aspect deciding on the practical success of a management theory is the motivation of personnel, the training and change of organisational culture. Without 
a change in thinking, each hospital management innovation will be resisted by the medical staff (Toffler, 1984).

The key performance indicator and cost control models are becoming more and more complex and detailed, and include an even lower level of functions and management processes as well as elements of organisational structures. This all translates to increasing demand for multi-dimensional databases that are available, up to date and accurate. Key aspects of hospital management may include connecting data made available by the NFZ concerning DRGs with data from the hospital IT system and performance management tools, and provision and visualisation of historical data, including the possibility of multi-level drill down analysis.

Hospital cost management, regardless of whether it's strategic, tactical, or operational, should take into account the costs in the DRG dimension, since it forms the basis for settlement with the payer. The DRG Statistics website (National Health Found, n.d.) provided by the NFZ presents patient treatment costs divided by type of hospital, NFZ ward, sex, and age group. The hospital costs most frequently depend on: a) complexity of the patient's illness, b) the patient's health (planned or unplanned admittance), c) medical diagnosis etc. Comparing the cost-related data for a specific period with the average value provided by the NFZ enables hospital managers to plan directions of development and to establish financial plans. In order to supplement the DRG data from their own IT system, the hospital management may use such sources as:

- analysis of health care services usage (National Health Found, 2010),

- length of time on waiting lists,

- the structure of surplus performances of hospital services (National Health Found, 2011a),

- financing of hospitalisation for patients 65 years and older (National Health Found, 2011b).

To effectively use DRG data we require the knowledge of:

a) planned contracts (volume and value of services) according to DRG unit,

b) detailed historical data from previous years (volume and value of contracts) also according to DRG; surplus performances; queue length of waiting patients,

c) actual costs of services compared with the DRG price, established by the NFZ,

d) deviation between actual and planned costs.

To fully use the available information, the presence of a "controller" in the hospital is necessary - that is, a person who would connect external 
Piotr Szynkiewicz et al.

data sources with information from the hospital IT system, concerning the possibility of obtaining necessary analyses efficiently.

\section{Analysis of the Demand for Business Performance Management Tools by Hospital Staff}

The connection of medical and economic goals is a problem for hospital managers. Economic goals impact the method of management, which becomes "geared towards the medical services market, the rational use of possessed resources and the provision of services in accordance with medical art" (Zbroja, 2001). In this section, we will first present the results of a poll conducted among 40 representants of hospital management, and then describe what requirements must be met by a hospital business performance management support system.

What financial indicators are important for the hospital? What is the difference between hospitals and other entities concerning finances? Should hospitals use different indicators than other companies? What indicators are critical for the operational management of a hospital? The primary indicator is whether the hospital bears a profit or loss. Depending on the level of management to which such information is available, various possibilities of monitoring and managing the level of costs and profits will be available. Examples of multiple government programs, intended to remove the debts of public hospitals emphasize the role of indicators in describing such areas as: a) debt; b) liquidity; c) liabilities. Liabilities, depending on the criterion used, may be divided by: a) maturity - into short-term (up to a year) and long-term; b) depending on the entity - public-private; private companies; crews; c) intended use of the resources - investments, current operation.

The poll conducted among hospital managers who participated in the Congress of Health Care Management Practitioners as a part of the "Medical Information Platform" project indicates that the biggest problems in medical entity business performance management include low awareness of the impact of decisions made on the financial results of the hospital among the medical personnel, lack of information concerning the operation of the ward/hospital compared to other hospitals, hospital personnel not maintaining budget discipline, lack of rapid access to financial and medical reports in hospital IT systems, and problems with motivating personnel - no possibility of defining tasks and assessing their implementation based on the hospital's financial and medical data (pinmed.pl, 2012a). 
The most common measures of results among the studied hospitals included the number of readmissions within 30 days of discharge, per 100 discharges, the number of hospital infections per 1000 hospitalisation persondays, the number of repeated surgeries per 100 performed surgeries (KozunCieślak, 2012). Based on the polls, it was established that the key reports for hospital management are profitability by DRG groups, budget performance reports on the hospital ward level and analyses for the preparation of strategic or financial plans (Kozuń-Cieślak, 2012). The surveyed persons indicated the following as the most frequently used indicators concerning the transformation of costs into hospital results: the number of medical personnel (doctors, nurses, midwifes) per 100 beds, the total costs of medication per 1000 hospitalisation person-days, the total costs of diagnostics per 1000 hospitalisation person-days, and the total costs of the hospital per 1000 hospitalisation person-days (Kozun-Cieślak, 2012). The surveys show that the key information and analyses in the contracting process include changes in NFZ expenditure by types of services provided within the country as a whole and in particular provinces, changes in the value of contracts within chosen scopes (specialities), and changes in the value of contracts within individual hospitals of a province during the last three years (pinmed.pl, 2012b). According to hospital management, the limits and barriers to implementation and use of business performance management are: the fact that the performance goals are not included in the motivation/bonus system and lack of indicators for monitoring execution of the performance goals (KozunCieślak, 2012). From the responses provided by hospital management it can be seen that the main restrictions in the process of business performance management implementation include lack of management reports on hospital IT systems, the insufficient budgeting functionality in Hospital IT systems, and lack of information on financial and medical parameters of similar hospitals by DRG, which hinders planning and introduction of changes (Kozuń-Cieślak, 2012).

Decision supporting systems analyze the basic requirements for hospital business performance and management, which may be formulated in the following areas:

a) Access to data - from any place and at any time. This requirement means that a web browser has an advantage over a spreadsheet and/or other data access interfaces.

b) Data being up to date - the requirements within this area establish the frequency of data aggregation and updating of information regarding the results. In small hospitals, the frequency of data updating may even be weekly, whereas in large hospitals it should be daily or even more frequently. 


\section{Piotr Szynkiewicz et al.}

c) Collection of data in a single application - This requirement facilitates the future development of the system and releases the user from having to switch between systems in order to obtain information.

d) Easy and rapid overview with the possibility of drilling down into details when needed.

Hospital management has at its disposal detailed DRG information from their own IT systems, unfortunately they are badly visualised. Hospital managers do not have the time to enter lengthy menus in order to generate a report, for which they must wait minutes or even dozens of minutes. Immediate information is needed, in order to establish whether the hospital is operating as planned, or there are deviations, and whether they are positive or negative. These requirements are met by modern manager dashboard systems, which enable drilling down into data, and thus, seeing even more details.

\section{Discussion}

Managing the efficiency of medical entities, in particular of hospitals, is a relatively new phenomenon in Poland. Studies by Malinowska-Misiąg et al. (2008) emphasise the role of hospital management staff in achieving a positive financial result.

Initiatives that connect actions related to effectiveness and efficiency implemented by service providers in hospitals with actions on a general level of the country will enable hospital managers to compare the level of their achievements with general achievements for the country. A special role should be played by internet websites providing data about effectiveness and efficiency, modelled on such systems as: Comparative Effectiveness Resource Center (ECRI Institute, n.d.), Health Care Cost Institute (n.d.), Medicare.gov Hospital Compare (n.d.), and Becker's Hospital Benchmarks.

The Polish market lacks aggregated, depersonalised data such as costs, profits and effectiveness of individual hospitals for specific DRG groups. This gap is filled by a solution by the "Prometriq Akademia Zarzadzania" (Prometriq Academy of Management) company from Sopot. Using the "Medmetriq - medical and financial controlling" application for medical and financial controlling, the hospital may use the profit maximisation and cost optimisation model, using such functionalities as:

a) analysis of cost levels,

b) analysis of factors which impact the costs and their change over time (for example the duration of hospitalisation), 
c) benchmarking - comparing the hospital's results with the results of other hospitals, including the comparison of the costs of treatment by DRG,

d) controlling the performance of the contract and payment by the NFZ,

e) analysis of the use of resources and costs at the DRG level,

f) comparison of the treatment costs of a specific patient with the averages for a given DRG group.

According to Morard and Huber, the Activity Based Costing (ABC) method is expensive and "the main problem of small hospitals is the lack of information on the use of resources by the patient" (Morard et al., 2000). The direction of the future development of the Medmetriq system is to provide evidence-based information for patients (ECRI Institute, 2009).

IT services and systems are one of the elements which decide on the implementation of business performance management, which can be seen best in data concerning expenses for the computerisation of hospitals. In old EU countries, hospitals invest heavily in ICT (Information and Telecommunication Technology). The forecasts made by the European Coordination Committee of the Radiological, Electromedical and Healthcare IT Industry for 2015 estimate the value of these investments at a level of $€ 2.762$ billion (COCIR, January, 2012).

\section{Conclusion}

It is not possible to increase the effectiveness of operation of healthcare entities without increasing the importance of IT systems and using DRGs more effectively in the management process. Training users in IT and the use of DRGs is important to achieving hospital effectiveness. The increased importance of technology in hospitals should be reflected in the organisational structure of service providers. The hospital controller should have a similar role to one present in most companies in other industries. This will facilitate the implementation of new IT solutions in a manner ensuring their proper use.

It is becoming necessary to move from the collection of patient medical data towards actively using them in the process of medical decision making. The use of DRGs should become a decision supporting tool in the hospital management process.

A detailed calculation of costs of services may be used beyond planning the profitability of services which are settled with the NFZ based on the DRG system. Knowledge of actual costs is the basis for negotiations with 


\section{Piotr Szynkiewicz et al.}

companies which provide additional insurance services. Moreover, knowledge of the level of service costs enables the use of voluntary pricing policy on the commercial services market.

Health service reforms, namely the restructuring and transformation of hospitals, force the introduction of new management method solutions, new approaches towards costs, effectiveness and efficiency of work. The DRG system without doubt should be a component of the new tools. The system is used in most OECD countries. Hospitals in Poland have already implemented an IT system which provides reports to the public payer (NFZ) in accordance with DRGs. It is now time to use this information in the hospital management process.

The goal of controlling and efficiency management should be to improve the results of medical entities. If the analyses and controlling actions have no impact on the results, they are unnecessary and should not be used by hospitals. We hope that in the conditions of the market-oriented shift in health care and increased emphasis on effectiveness, the demand for supporting systems that improve the effectiveness of management in Polish hospitals will increase.

\section{R E F E R E N C E S}

COCIR, European Coordination Committee of the Radiological, Electromedical and Healthcare IT Industry (2012, January). Hospitals' use and investment plans towards 2015 for health ICTs. Retrieved from http://www.cocir.org/ uploads/documents/-1386-cocir_market_intelligence_update_health_icts_13_ january_2012.pdf.

ECRI Institute (2009). The Federal Coordinating Council for Comparative Effectiveness Research. Listed panel - June 10, 2009. Vision for a National Patient Library. Statement by Jeffrey C. Lerner, Ph.D., President and CEO, ECRI Institute. Retrieved from https://www.ecri.org/Forms/Documents/ National_Patient_Library_Whitepaper_061609.pdf.

ECRI Institute (n.d.). Comparative Effectiveness Resource Center. ECRI Institute. Retrieved from https://www.ecri.org/comparativeeffectiveness/Pages/ default.aspx.

Gierusz, J., \& Cygańska, M. (2009). Budżetowanie kosztów działań w szpitalu. Gdańsk: ODDK.

Hass-Symotiuk M. (Ed.). (2011). System pomiaru i oceny dokonań szpitala, Warszawa, Polska: Wolters Kluwer Polska.

Health Care Cost Institute (n.d.). Retrieved from http://www.healthcostinstitute. org/.

Jaworzyńska, M. (2010). Planowanie finansowe w zaktadach opieki zdrowotnej. Warszawa, Polska: CeDeWu. 
Diagnosis-Related Groups (DRG) and Hospital Business Performance...

Kozuń-Cieślak, G. (2012). Ankieta dotyczaca doboru mierników nakładu i rezultatu w celu szacowania efektywności szpitali metoda DEA. Perspektywa organu założycielskiego: cel zorientowany na stan zdrowia pacjentów. Kongres Praktyków Zarządzania w Ochronie Zdrowia, "MEDMETRIQ 2012", Sopot, Poland.

Malinowska-Misiąg, E., Misiąg, W., \& Tomalak, M. (2008). Zarzadzanie środkami publicznymi w polskich szpitalach. Warszawa, Polska: Instytut Badań Nad Gospodarką Rynkową.

Medicare.gov (n.d.). Hospital Compare. Retrieved from http://www.medicare.gov/ hospitalcompare/search.html?AspxAutoDetectCookieSupport=1.

Morard, B., \& Huber, Z. (2000). Quels coûts pour quels produits hospitaliers? Le secteur de la santé face au besoin d'information en matière de coûts. L'Expert-comptable suisse 1-2, 41-50.

National Health Fund (2010). Analysis of health care services usage. Retrieved from http://www.nfz.gov.pl/new/index.php?katnr=8\&dzialnr=2\&artnr=4092.

National Health Fund (2011a). The structure of surplus performances of hospital services. Retrieved from http://www.nfz.gov.pl/new/index.php?katnr=8\& dzialnr $=2 \&$ artnr $=4625 \& b=1 \&$ szukana $=+$ analiza +2010.

National Health Fund (2011b). Financing of hospitalisation of patients since 65 years and older Retrieved from http://www.nfz.gov.pl/new/index.php?katnr $=8 \&$ dzialnr $=2 \& \operatorname{artnr}=4378$.

National Health Fund (n.d.). DRG Statistics. Retrieved from http://prog.nfz.gov.pl /APP-JGP/.

pinmed.pl (2012a). Ankieta na potrzeby projektu Platforma Informacji Medycznych. Platforma Informacji Medycznych pinmed.pl - projekt NCBiR. Retrieved from http://pinmed.pl/.

pinmed.pl (2012b). Kongres Praktyków Zarządzania w Ochronie Zdrowia Medmetriq 2012. Platforma Informacji Medycznych pinmed.pl. Retrieved from http://pinmed.pl/.

Rój, J., \& Sobiech, J. (2006). Zarzadzanie finansami szpitala. Warszawa, Polska: Wolters Kluwer Polska.

Stępniewski, J. (Ed.). (2008). Strategia, finanse i koszty szpitala. Warszawa, Polska: Wolters Kluwer Polska.

Toffler, A. (1984). Future Shock. New York: Bantam Books.

Ustawa z dnia 15 kwietnia 2011 o działalności leczniczej (2011). Dz. U. 2011 vol. 112 item 654. Retrieved from http://isap.sejm.gov.pl/DetailsServlet?id=WDU20 111120654 .

Zbroja, A. (2001). Decyzyjny rachunek kosztów w szpitalu - konieczność czy alternatywa? In: K. Krajewski, \& M. Wójtowicz (Eds.), Zarzadzanie finansami placówek medycznych. Warszawa, Polska: Instytut Przedsiębiorczości i Samorządności. 